\title{
Exploring the Relationship between Critical Thinking Skills and Academic
}

\author{
Achievement \\ * Uzma Shahzadi, Assistant Professor \\ ** Nimmi \\ *** Dr. Itbar Khan
}

\begin{abstract}
The present study investigated the correlation of critical thinking skills (CTS) and academic achievement of intermediate students in the province of Punjab, Pakistan. The study was quantitative. The population of the study comprised all the students enrolled for intermediate in the province of the Punjab. Multistage sampling technique was used to select a sample size of 300. CTS test scores were obtained from a self-developed multiple-choice test having dimensions of analysis, evaluation, and logic. Scores of the academic achievement was obtained from the selected sample. It was found that the majority of students at intermediate level performed low on analysis, evaluation, and logic dimensions of the critical-thinking skills. The study also revealed that there was a significant positive relationship between CTS and academic achievement of students at the intermediate level. The study recommends introducing teacher guides for teaching CTS at the intermediate level. The study also recommends introduction of continuous assessment procedures for the development of the CTS in students at the intermediate level.
\end{abstract}

Keywords: Critical Thinking Skills; Academic Achievement; Scores, Critical Thinking Skill Test Introduction

Since long, Critical thinking skill has been considered as a fundamental aim of education. Educational institutions are required to teach students to think critically and grow. (Paul \& Willsen, 1995). Critical thinking skill is the requirement of not only learning place but it is the prime requirement at the workplace. Demanding economy and technological complexity requires workers who are problem solvers and critical thinkers. This is the reason that critical thinking is the part of many scholarly works, theories and reforms in the field of education (Elder, 2005; Ennis, 1997; Paul \& Willsen, 1995; Faccione, 1992; Fisher, 2001; Halpern, 1998; McPeck, 1990; Siegel, 1988; Swartz, 1994). Along with these theorists, the concept of critical thinking has been advocated by many others who worked on the critical thinking skills, dispositions and they concluded that paying more attention to an active state of students and teacher is a focusing trend in education(Slavin,2005; Gralewski \& Karwowski,2012; Eggen \& Kauchak, 2001; Cottrell,2017).

However, the change, is being observed more carefully as the $21^{\text {st }}$ century approached. It is thought of as an age of transition that is overloaded with information which calls for re-examination, analysis, and re-evaluation by the learners. The re-examination, analysis, and evaluation are important dimensions of CTS (Wagner, 2008). As narrated by Chaffee (2014) that the ever-changing world needs CTS to be successful in life. It is required, as mentioned in the literature that classrooms should focus on the development of CTSin students and it is the prime responsibility of the classrooms and ultimately educational institutes (Sternberg, 2003).

Similarly, Facione (1990) argues that there is a need to equip students with habits of inquiry and cognitive skills that are related to critical thinking skills. Hence, the inclusion of CTS in curriculum and teaching these skills is of utmost importance in the current world where there is a flood of information and complexity (Lipman, 1987; Ennis, 1998; Facione, 2000; Halpern, 1998). By teaching CTS means, students are taught to engage in better thinking, whereby they exploit the criteria and standards for thinking which can be assessed by their thinking and involved in practical reasoning (Weiler, 2005). This has been defined in various ways but it is often coupled with the skills to

\footnotetext{
* Department of Education, University of Sargodha Email: uzmashah_bzu@yahoo.com

** Vision College, Multan

*** Department of Education and Training, University of Malakand
} 
observe and inquire problems, weighing solutions, judging the quality of facts, evaluate the situation, known of implicit assumptions and consider the potential problem solutions.

It might be seen as focused and guided thinking by rational facts, involve productive questioning (DiYanni, 2015). In the requirement of developing these analytical skills, learners need to be given the opportunities to question which will depend upon learning situations that are open and provide students to interact with each other, with the resources and with the teachers (Paul \& Edler, 2007). It is also thought that active learning promotes the habit of thinking among students about what they are doing (Van Amburgh, Devlin, Kirwin \& Qualters, 2007) and such thinking powers have a positive effect on their academic achievement.. This research study is a contribution in assessing the critical thinking skills among students at intermediate level and it provides an understanding to the relationship of critical thinking skills and academic achievement of the students.

\section{Literature Review}

It is noted that, researchers and educators all over the world generally believe that CTS play a vital role in students' academic achievement. Academic achievement is the term, used to define the upward progress in achieving predetermined goals of education, thought to be one of the most important indicators to measure the students' abilities and knowledge. Putwain and Daniels (2010) defined academic achievement, to be master of all the information and the theoretical knowledge gained in a special field or a particular course. Generally, the concept of academic achievement has long been concerned as directly related to the concept of mental attributes i.e. intelligence. The person having a high IQ level can better perform in the educational field by memorizing all the theoretical knowledge. Now in the $21^{\text {st }}$ century, only IQ is not the only indicator of success.

However, in addition to these CTS and thinking, dispositions are also considered to play a great role in the success of an individual. Hence, Students differ in their academic achievement not only because of intelligence but other factors with mental abilities also contribute to their academic achievements (Ahvan \& Pour2017). Among these factors, that are associated with academic achievement, critical thinking skill is thought to be the most important factor. This is the reason that focus on curricular content has been shifted to curricular outcomes and ultimately to the student competencies that most often, is discussed as market needed competencies or also as life based skills.

Many researchers worked in this particular field to find out the relationship between CTS and the academic achievement of the students. In this respect there are several studies where researchers have found a significant relationship between these two variables (Fong et al., 2017; Ghanizadeh, 2017; Vierra, 2014; Ross at al., 2013). They found that CTS positively affects academic achievement and contributes to students' success in the academic field. On the contrary, some researchers found no significant relationship between them (Ahanchian \& Bakhshi, 2013; Bazalais, Doleck, Lemay, Saxena, \& Basnet, 2017). They did not found a positive or negative effect on the academic achievement of the students as they found no correlation between CTS and their academic achievement.

Hence, previous studies in this field are contradictory, so this relationship needs to be analyzed systematically before giving any concluding remarks. Demographic factors such as age, gender, ethnicity, and academic discipline have been examined by many researchers (Aliakbari \& Sadeghdaghighi, 2011; Kathiravelu, Tapsir, \& Osman, 2004; Leach, 2011). Numerous studies in this respect found that sometimes differences in results occur due to gender. Many researchers found males are better than females concerning critical thinking skills. Some have the view that females have more thinking powers than males.

On the contrary, there are also many studies where researchers found no significant difference between male or female in this respect. Hence, they also provide a contradictory picture favouring both men as well as women (Giancarlo \& Facione, 2001; King, Wood, \& Mines, 1990). The same is the case with academic disciplines where some researchers found the difference between Science students and the students of Arts in the CTS test. Many found Science students have more thinking powers than Arts students (Mahdyeh \& Arefi, 2014). Others found no significant difference among them. Despite of all such confusing situation, development of CTS among students at all levels of education is an important objective of educational institutes across the globe.

In order to facilitate the transition of students' knowledge and skills into responsible civic actions and economy players, it is the utmost requirement of the academia and academic institutes to 
address the development of CTS among students (Zoller,2001). T In general, academia as well as market experts focus that the ability and development of an ability to think critically should be an imperative for success in today's modern life. It is also observed that the pace of change is supposed to continues to gear up causing interdependence, complexity to intensify the available scenario and need for critical thinking (Miri, David \& Uri,2007). There is always a need for continuous learning and many research studies support that CT Sof individuals substantially support the lifelong learning. It is also observed that research recommends to redesign the courses so that they may assist students become lifelong learners and continue learning even after their studentship ends.

This is the reason, that the researchers tried to research the critical thinking skill of the students at the intermediate level. Existence of critical thinking skill, the difference of student's thinking powers due to gender and discipline and the relationship between critical these skills and academic achievement of the student were analyzed here by the researcher in a systematic way by getting data from three districts of Punjab, Pakistan to give the final verdict. Friedel et al. (2006) also observed that teaching of these skills prove helpful in increasing critical thinking skill of the students in colleges. Moreover, Rudd, Baker, and Hoover (2000) argued for greater study of such skills among the students of agriculture that critical skills may be given more space in curricula (p.2).

\section{Methodology}

The study was quantitative and correlational. It was mainly aimed at finding out the correlation of CTS and academic achievement of the students at the intermediate level in three districts of Punjab; Sahiwal, Khanewal, and Vehari. The study population was students enrolled in the intermediate level in province Punjab, Pakistan. Multistage sampling technique was used to select a sample. A total of 300 students made the sample size of the study. CTS test was developed by the researchers by consulting the analytical and logical part of a test conducted by national testing service in Pakistan, known as the national aptitude test (NAT). The test was validated by expert opinion and reliability estimate was established by Kuder Richardson-20 and it was found to be .78. The CTS test was comprised 40 multiple-choice items. The item was scored 0 and 1 for the wrong and right answers. Scores in a multiple-choice CTS test and academic achievement were correlated using Pearson's " $r$ ". Academic achievement of the students were the marks in board exams for the session 2015-2016, collected from contacting administrative offices in the concerned colleges and gazette of the year. Students were ranked high with achievement of $60 \%$ and above while students with marks percentage $50 \%-59 \%$ were ranked average and students with mark percentage lowest than 50\% were tanked satisfactory.

\section{Analysis}

Pearson's " $\mathrm{r}$ " was used to determine the correlation of critical thinking skill and academic achievement of students at the intermediate level. SPSS version 22 was used for the analysis of the data collected. Minimum, maximum, mean scores and standard deviation was calculated. Furthermore, skewness and kurtosis values were also computed using SPSS and the values were .857 and 1.74. From literature it is explored that the prescribed range of normality is between .1.96 to 1.96. Table 1 represents the mean scores of sampled students on the analysis, evaluation, and logic dimension of the CTS Test (CTST).

Table 1:

Mean score performance of students on critical thinking skill test (CTST)

\begin{tabular}{lccccc}
\hline $\begin{array}{l}\text { Dimensions of Critical } \\
\text { Thinking skill }\end{array}$ & $\mathrm{N}$ & Minimum & Maximum & Mean & Std. Deviation \\
\hline Analysis & 300 & 0 & 4 & .87 & .86 \\
Evaluation & 300 & 0 & 3 & .79 & .75 \\
Logic & 300 & 0 & 3 & .59 & .72 \\
Overall & 300 & 0 & 10 & .75 & .77 \\
\hline
\end{tabular}

Table 1 represents that students scored .87 on the dimension of analysis of critical thinking skill test and .79 on evaluation of critical thinking skill test and .59 on logic development of critical thinking skill test. Table 1 further reveals that students achieved low scores on critical thinking skill tests and among the three dimensions the logic development dimension is comparatively weaker area of students' performance on the critical thinking skill test. 
Table, further, shows that the overall mean score on the critical thinking skill test is .75 and the maximum score is 10 from a total score of 40 . The table, further, represents the low performance of students on CTS tests at the intermediate level.

Table 2

Academic Achievement of Students at Intermediate Level

\begin{tabular}{lllllc}
\hline Marks Range & Rank & $\mathrm{N}(300)$ & Percentage & Mean & Std. Deviation \\
\hline $400-550$ & Satisfactory & 17 & $5.6 \%$ & 690.70 & 82.87 \\
$551-700$ & Average & 138 & $46 \%$ & & \\
$700-895$ & High & 145 & $48.3 \%$ & &
\end{tabular}

Table 2 represents the academic achievement of students. $60 \%$ and above achievement is placed in high rank, 50\% and above are placed in average rank, and students achieved below 50\% are places in satisfactory rank. The marks range of students shows that the majority of students in a high range of marks i.e., above 60. 17 students have reported marks between400-550, 138 students reported their marks between marks range 551-700 and majority of students i.e., 145 reported marks in the range of 700-895.

Table 3

Relationship of CTS and academic achievement of students at the intermediate level

$\mathrm{N} \quad \mathrm{R} \quad(\mathrm{r})_{2} \quad \mathrm{P}$-Value

CTS \& Academic Achievement

$\begin{array}{llll}300 & .16 & .025 \quad .00\end{array}$

Table 3 reveals that the relationship between CTS(CTS) and Academic achievement of the students at the intermediate level is significant. Correlation coefficient $(r)$ is .16 , and $r_{2}$ is .025 indicates that there is 2.5 percent shared variance. The table also reflects that $\mathrm{P}<.05$.

\section{Relationship between CTS and academic achievement based on Gender}

Pearson Product Moment correlation(r) was used to find out the relationship between the CTS and the academic achievement of male students.

Table 4

Correlation between critical thinking skill and academic achievement based on Gender

\begin{tabular}{lllll}
\hline $\mathrm{N}$ & $\mathrm{R}$ & $\mathrm{r})_{2}$ & $\mathrm{P}-$ Value \\
\hline
\end{tabular}

CTS \& Academic Achievement (Male)

$\begin{array}{lll}150 & .187 \quad .035 \quad .022\end{array}$

CTS \& Academic Achievement (Female)

$\begin{array}{llll}150 & .14 & .019 & .12\end{array}$

Table 4 shows that there is a significant positive relationship between academic achievement and CTS of male students at intermediate level as $\mathrm{p}<.05$ while there is no significant positive correlation ship between academic achievement and CTS scores of female students as $p>0.05$. academic achievement of the students at the intermediate level is positive. Correlation coefficient ( $r$ ) is .14 , and $r_{2}$ is .019 indicates that there is a 1.96 percent shared variance. The table also reflects that $\mathrm{p}>, 05$.

Relationship between CTS and Academic achievement based on Discipline

Relationship between CTS and academic achievement of Arts students was also analyzed with the help of Pearson product-moment Correlation (r) as under: 
Table 5

Correlation between Critical Thinking skill and academic achievement of Arts students at intermediate level

\begin{tabular}{lcccc}
\hline & $\mathrm{N}$ & $\mathrm{R}$ & $\mathrm{r} 2$ & P-Value \\
\hline $\begin{array}{l}\text { CTS } \\
\text { \& Academic Achievement } \\
\text { (Arts) }\end{array}$ & 150 & -.015 & .00025 & .86 \\
$\begin{array}{l}\text { CTS } \\
\text { \& Academic Achievement } \\
\text { (Science) }\end{array}$ & 150 & .3 & .073 & .00 \\
\hline
\end{tabular}

Table 5 reflects that the relationship between CTS and academic achievement of the students enrolled in arts subjects at intermediate level is not a significant relationship of as $\mathrm{P}>.05$. Table, further, reveals that the relationship between CTS and academic achievement of the students enrolled in science subjects at the intermediate level is positively correlated.

\section{Discussion}

The study aimed at exploring the correlation of CTS and academic achievement of the student. To achieve the objective of the study, correlational design was carried out; three dimensions of critical thinking skill were explored by critical thinking skill test. The study revealed that students at intermediate level performed lower in all three dimensions of critical thinking skill test. This is in line with the study conducted by Grosser (2013) that concluded the lower performance of students on CTS test. The study results were also in agreement with the findings of the study by Paul and Elder (2008) that posted that students are not well critical thinkers. Similarly, studies also aligned the current study that the results, average to poor were obtained by the participants and it indicates that they have not yet demonstrated the development of interrelated cognitive and meta-cognitive skills that are needed for the execution of critical thinking (Halpern, 2007; Halx \& Reybold, 2005, Shinnick \& Woo, 2013). The present study revealed that there is a weak positive relationship between the critical thinking skill and academic achievement of the students at the intermediate level. Further, the study revealed that CTS are positively correlated with their academic achievement, when data was analyzed gender-wise i.e., male and female students at the intermediate level. The results are in line with Myers and Dyers (2006) who found no significant relationship between critical thinking levels and gender. While Science students' CTS are positively correlated with academic achievement while arts students' CTS are negatively correlated with their academic achievement. These findings concur with Rodrigues and Oliveira (2008) who claimed that Physics a science subject supports the development of CTS among students. Similarly, the findings also are in line with the findings by Kanbay and Okanli (2017) who claimed that there is no significant relationship between CTS and academic achievement of students enrolled in arts disciplines. The overall results show a weak positive significant relationship between the CTS of students at intermediate level and academic achievement. This finding is consistent with Ghazivakili et al. (2010) who found that CTS play a role in the academic performance of the students and there is a positive and significant relationship between CTS and academic performance of graduates.

\section{Conclusions and Recommendations}

The study concluded that overall performance of intermediate students in critical thinking test is scored low. It was also concluded that among three dimensions considered in this study, the logical development score lower as compare to other two dimensions i.e., analysis and evaluation. The study, further, concluded that there is positive correlation between CTS and academic achievement of science students while no significant correlation is found between CTS and academic achievement of the arts students. The current study recommends that curriculum reforms focusing on CTS at the intermediate level should be implemented. At intermediate level no teacher guides are available to guide teachers to develop CTS among students so teacher guides might be prepared and provided to the public sector colleges. Continuous assessments might be used to develop CTS in students. Teacher training institutes/colleges and institutes of Education and Research in universities may include a subject on the development of CTS in prospective teachers. Most of the teacher education curricula in 
Pakistan do not have a course on CTS and even most of the teacher educators are unaware of how to teach critical thinking skills. The study also recommends conducting a review research to know the prevailing level of CTS among students at an intermediate level in all provinces with larger sample sizes and more standardizes critical thinking skill test

\section{References}

Ahvan, Y. R., \& Pour, H. Z. (2016). The Correlation of Multiple Intelligences for the Achievements of Secondary Students. Educational Research and Reviews, 11(4), 141-145.

Aliakbari, M., \& Sadeghdaghighi, A. (2011, August). Investigation of the relationship betweengender, field of study, and critical thinking skill: The case of Iranian students. In The 16th

Conference of Pan-Pacific Association of Applied Linguistics. The Chinese University of Hong Kong.

Bakhshi, M., \& Ahanchian, M. R. (2013). A proposed model to predict academic achievement: the role of critical thinking and self-regulated learning strategies. Iranian journal of medical education, 13(2), 153-163.

Cottrell, S. (2017). Critical thinking skills: Effective analysis, argument and reflection. Macmillan International Higher Education.

DiYanni, R. (2015). Critical and creative thinking: A brief guide for teachers. John Wiley \& Sons.Doleck, T., Bazelais, P., Lemay, D. J., Saxena, A., \& Basnet, R. B. (2017). Algorithmic thinking, cooperativity, creativity, critical thinking, and problem-solving: exploring the relationship between computational thinking skills and academic performance. Journal of Computers in Education, 4(4), 355-369.

Eggen, P. D., \& Kauchak, D. P. (2006). Strategies and models for teachers: Teaching content and thinking skills. Boston, MA: Pearson/Allyn and Bacon.

Elder L \& Paul R (2008). Critical thinking in a world of accelerated change and complexity. Social Education, 72(7):388-39

Elder, L. (2005). Critical thinking as the key to the Learning College: A professional development model. New Directions for Community Colleges, 2005(130), 39-48

Ennis, R. H. (1997). Incorporating critical thinking in the curriculum: An introduction to some basic issues. Inquiry, 16(3).

Facione, P. A. (1990b). The California CTS Test: College Level Technical Report --Experimental Validation and Content Validity. California Academic Press

Facione, P. A. (2000). The disposition toward critical thinking: Its character, measurement, and relationship to critical thinking skill. Informal logic, 20(1).

Facione, P. A., Facione, N. C., \& Giancarlo, C. A. F. (2001). California critical thinking disposition inventory: CCTDI. California Academic Press.

Fisher, A. (2001). Critical Thinking - An Introduction. Cambridge: Cambridge University Press.

Fong, C. J., Kim, Y., Davis, C. W., Hoang, T., \& Kim, Y. W. (2017). A meta-analysis on critical thinking and community college student achievement. Thinking Skills and Creativity, 26, 7183.

Friedel, C. R., \& Rudd, R. D. (2006). Creative thinking and learning styles in undergraduate agriculture students. Journal of Agricultural Education, 47(4), 102.

Ghanizadeh, A. (2017). The interplay between reflective thinking, critical thinking, self- monitoring, and academic achievement in higher education. Higher Education, 74(1), 101- 114.

Ghazivakili, Z., Nia, R. N., PANAHI, F., Karimi, M., Gholsorkhi, H., \& Ahmadi, Z. (2014). The role of CTSand learning styles of university students in their academic performance. Journal of advances in medical education \& professionalism, 2(3), 95.

Gralewski, J., \& Karwowski, M. (2013). Polite girls and creative boys? Students' gender moderates the accuracy of teachers' ratings of creativity. The Journal of Creative Behavior, 47(4), 290304.

Grosser, M. M., \& Nel, M. (2013). The relationship between CTS and the academic language proficiency of prospective teachers. South African Journal of Education, 33(2).

Hall MD \& Reybold LE 2005. A pedagogy of force: faculty perspectives of critical thinking capacity in undergraduate students. The Journal of General Education, 54:293-315. 
Halpern DF 2007. The nature and nurture of critical thinking. In R Sternberg, HL Roediger III \& DF Halpern (eds). Critical thinking in psychology. New York: Cambridge University Press.

Halpern, D. F. (1998). Teaching critical thinking for transfer across domains. Dispositions, skills, structure training, and metacognitive monitoring. The American Psychologist, 53(4), 449.

Kanbay, Y., \& Okanl1, A. (2017). The effect of critical thinking education on nursing students' problem-solving skills. Contemporary nurse, 53(3), 313-321.

Kathiravelu, A., Tapsir, R., \& Osman, A. M. (2004). Metacognitive and critical thinking abilities of students at INTEC.

King, P. M., Wood, P. K., \& Mines, R. A. (1990). Critical thinking among college and graduate students. The Review of Higher Education, 13(2), 167-186.

Leach, B. T. (2011). CTS as Related to University Students Gender and Academic Discipline.

Lipman, M. (1987). Critical thinking: What can it be? Analytic Teaching, 8(1).

Mahdyeh, N., \& Arefi, M. (2014). A Comparison of Critical Thinking, Self-Efficacy and Academic Performance among Students of the Faculty of Humanities and Engineering. Indian Journal of Fundamental and Applied Life Sciences, 4(1), 153-162.

McPeck, J. (1990). Critical Thinking and Subject Specificity: A Reply to Ennis. Educational Researcher, 19(4), 10-12.

Miri, B., David, B. C., \& Uri, Z. (2007). Purposely teaching for the promotion of higher-order thinking skills: A case of critical thinking. Research in science education, 37(4), 353-369.

Myers, B. E., \& Dyer, J. E. (2006). The influence of student learning style on critical thinking skills. Journal of Agricultural Education, 47(1), 43.

Paul, R., \& Willsen, J. (1995). Accelerating change, the complexity of problems, and the quality of our thinking. Foundation for Critical Thinking.

Putwain, D. W., \& Daniels, R. A. (2010). Is the relationship between competence beliefs and test anxiety influenced by goal orientation?. Learning and Individual Differences, 20(1), 8-13.

Ramos, J. L. S., Dolipas, B. B., \& Villamor, B. B. (2013). Higher-order thinking skills and academic performance in physics of college students: A regression analysis. International Journal of Innovative Interdisciplinary Research, 4(1), 48-60.

Rodrigues, A., \& Oliveira, M. (2008). The role of critical thinking in physics learning. Thinking through Physics education.

Ross, D., Loeffler, K., Schipper, S., Vandermeer, B., \& Allan, G. M. (2013). Do scores on three commonly used measures of critical thinking correlate with the academic success of health professions trainees? A systematic review and meta-analysis. Academic Medicine, 88(5), 724-734.

Rudd, R., Baker, M., \& Hoover, T. (2000). Undergraduate agriculture student learning styles and critical thinking abilities: Is there a relationship? Journal of agricultural education, 41(3), $2-12$.

Shinnick, M. A., \& Woo, M. A. (2013). The effect of human patient simulation on critical thinking and its predictors in prelicensure nursing students. Nurse Education Today, 33(9), 1062-1067.

Siegel, H. (1988). Educating reason: Rationality, critical thinking, and education. Routledge London.

Slavin, R. E., \& Davis, N. (2006). Educational psychology: Theory and practice.

Sternberg, R. (2003). Four alternative futures for education in the United States: it's our choice. School Psychology Quarterly, 18(4), 431-445. Retrieved from ProQuest Education Journal database. (AAT 611229291)

Swartz, R. J., \& Parks, S. (1994). Infusing the Teaching of Critical and Creative Thinking into Content: A Lesson Design Handbook for the Elementary Grades Instruction

Van Amburgh, J. A., Devlin, J. W., Kirwin, J. L., \& Qualters, D. M. (2007). A tool for measuring active learning in the classroom. American journal of pharmaceutical education, 71(5), 85.

Vierra, R. W. (2014). Critical thinking: Assessing the relationship with academic achievement and demographic factors.

Weiler, A. (2005). Information-seeking behavior in generation Y students: Motivation, critical thinking, and learning theory. The journal of academic librarianship, 31(1), 46-53.

Zoller, U. (2001). Alternative assessment as (critical) means of facilitating HOCS-promoting teaching and learning in chemistry education. Chemistry Education Research and Practice, 2(1), 9-17. 